\title{
Editorial: Marketing decision support - A new discipline for dot.coms and dinosaurs
}

'Show me your revenue model' said the third angel I'd met that day. I should explain that I had been over in New York with a dot.com looking for seed funding. Angels are the independently wealthy individuals who put in over 90 per cent of seed funding for dot.com ventures.

Revenue models for the dot.com start-ups are forecasts of future revenue. Angels subject these models to a process of due diligence, during which they cross-examine you on all the assumptions about web surfers in the future on which your revenue projections are based. They evaluate risks and rewards, and then decide where to place their bets.

As a visiting Professor of Marketing, at Cranfield School of Management, I have a personal interest in this decision process. Marketing is what powers the dot.coms. The angels give high premiums to powerful marketing. Forget the claims about Intel inside, the real power inside the dot.coms is their marketing. So how should decisions about the value of marketing be made?

At Cranfield School of Management we are taking that question very seriously. We have set up two research clubs recently, one to study best practice on marketing accountability, the other for best practice in emarketing.

We have found that the current methods used for valuation of dot.coms raise some important issues. Revenue models for dot.coms such as Amazon.com are based on the following logic: if there are one million records stored on the dot.com customer's database, and each customer has a disposable income of, say, $\$ 15,000$, then revenue modellers claim that the potential income is $\$ 15 \mathrm{bn}$. This assumes perfect cross-selling, meaning that this year's book-buyers will buy, next year, everything they need from the dot.com - books, CDs, clothing, automobiles, even food and drink.

An alternative revenue model can be found in the more mundane field of direct marketing. There, list-brokers trade computer files containing lists of customer details, similar to those valued so highly by Amazon.com. The list brokers, however, typically value each customer record at around ten cents, ie. 150,000 times less than the $\$ 15,000$ valuation claimed by the dot.coms.

It is, therefore, hardly surprising that the financial pages are starting to report rumours of the imminent bursting of the dot.com bubble. But, if the value of their marketing power is inflated, how should the value of marketing be calculated? And what logic should be used to support marketing decisions?

There are three key decision-support issues identified by members of the best practice research club. First, what information do stockbrokers and investors need to evaluate marketing? Secondly, 
how can we improve our

decision-making by adopting better techniques and models for calculating the value added by marketing? Thirdly, how can the board keep a tight rein on the internal execution of its marketing strategy?

Beginning with the information requirements of stockbrokers, venture capitalists and angels which have been studied intensely, both at the dinosaur and dot.com extremes. The qualities that investors are looking for in blue-chip dinosaurs are a mixture of financial and non-financial factors. Cash is king for conservative investors. But even blue-chip stocks, such as Coca-Cola and Ford, are valued at levels way above their cashflow projections. Dinosaur investors value the brands, as well as the bricks and mortar. Not all brands are valued equally. The value of the Rover brand will be decided in the coming weeks, and its valuation is likely to have a major impact on thousands of workers in the Midlands.

Cranfield has developed a five-factor model to guide organisations making decisions about the value of marketing. Marketing input, compared to international competitor levels, is the first factor. How do Rover's marketing investments match those of international competitors? Marketplace trends are next: what is happening to the areas of the market where Rover is strong? Then there is customer motivation: how do Rover drivers rate the brand as compared with drivers of competitor marques? Customer behaviour is the fourth factor: are Rover owners loyal? The final factor is outcome measures: how does last year's profitability compare with that of the competition?

Company reports and investor briefings do not generally reveal these important factors. Despite over 80 per cent of investment analysts wanting disclosure of these factors, less than 10 per cent of company reports disclose them, according to reliable research. Weather forecasting seems to be more of a preoccupation among dinosaur boards than brand valuation. Our reviews of company reports shows that the winter was warmer than expected for Centrica, and consumers were using too little gas, whereas the summer was too cold for lager drinkers according to Whitbread, Bass and Scottish and Newcastle.

The second best practice club issue is 'what good practices exist?'. My own research, for the Financial Times, The Economist Books, and the Marketing Council, show there to be a wealth of good practice. The problem is not lack of know-how, the real issue is that many of the leading-edge methods are not widely known at board level. Research firms such as Research International, Millward Brown, NOP and Taylor Nelson, all offer methods of gathering and analysing information about consumers and trade customers, that could provide just the information that the investment analysts want to see. Further, specialist valuation and modelling companies, such as Interbrand and my own consultancy Marketing Best Practice, can evaluate which factors are having the greatest impact on shareholder value. What is more these valuation methods apply equally to dot.coms and dinosaurs. Valuation models expose the links between marketing cause and financial effect. By exposing these links the investors can make up their own minds about equity value. Valuation models also show the risk profiles of the venture, which makes it easier to distinguish between the needs of different types of investor.

The third best practice club issue is how to keep a tight rein on the implementation of marketing strategy. Again, my research to date indicates a 
wealth of good practice, but limited knowledge and application of the methods among the business community. Professor Malcolm McDonald has developed marketing planning methods that are equally applicable to dot.coms and dinosaurs. Yet research indicates that less than 20 per cent of organisations apply these planning methods with any rigour. Scorecards for managers, and indicator panels for the entire organisation, can be developed to keep a tight rein on the implementation of marketing strategy. Already the balanced scorecard has been a big success outside the marketing area. It has great potential for marketing directors to keep control of the whole organisation's marketing efforts. Organisations that apply this decision-support approach find that it significantly improves their track record, and hence the value added by their marketing. The time and effort involved in taking marketing decisions using this disciplined approach is greater than using ad hoc methods, but reliable research shows that the success rate is much higher, and shareholder value creation is therefore much more certain. Experience also shows that sensible application of performance measures can enable marketing managers to reduce marketing waste, by providing early warning signals about any elements of the marketing mix that have below-average performance.

Marketing decision support is a new subject, but one that we believe has great value for dinosaurs and dot.coms. Its virtue is the accountability that it introduces into a field that traditionally has been dominated by hype, buzz and creativity. As the inevitable meltdown occurs, there will be a search for accountability and rationality. Marketing decision support can provide the solution for businesses that have 'marketing inside'.

ROBERT SHAW Visiting Professor of Marketing at Cranfield School of Management

C Robert Shaw 
